\title{
PERCUTANEOUS DISCECTOMY: A CURRENT TREATMENT FOR LUMBAR DISC HERNIATION
}

\author{
DISCOTOMIA PERCUTÂNEA: TRATAMENTO VIGENTE PARA HÉRNIA DE DISCO LOMBAR \\ DISCECTOMÍA PERCUTÁNEA: UN TRATAMIENTO VIGENTE PARA LA HERNIA DISCAL \\ LUMBARRESUMEN
}

Pablo Gerardo Lima-Ramírez'; David Benavides-Rodríguez ; Juan Yahir Viera-Ordóñez ; José Augusto Ruíz-Gurría',

Iván del Castillo-Vergara', Braulio Hernández Carbajal ${ }^{1}$, Diego Fernando León-López ${ }^{1}$

1. Hospital de Ortopedia para niños “Dr. Germán Díaz Lombardo", Módulo de Cirugía de columna vertebral y mínima invasión. México, D.F.

\begin{abstract}
Objective: Describe the functional outcomes of patients with contained lumbar disc herniation (L4-L5, L5-S1) treated with manual percutaneous nucleotomy (MPN) and demonstrate that it remains a technique with good results. Methods: A prospective, longitudinal study with 110 patients contained with lumbar disc herniation $(\mathrm{LDH})$ treated with (MPN). The evaluation was pre-surgical and 4, 30, 180 and 365 days after the surgery. We used Numeric Pain Scale (NPS), Oswestry Disability Index (ODI) and Macnab criteria. Descriptive and inferential statistics for differences. Results: N=110: 58 (52.72\%) men, 52 (47.27\%) women; average age 37.95 years (14-56) \pm 10.60 ; most affected level: L4-L5 in 63 (57.14\%) patients. NPS preoperative average: $7.75(5-9) \pm 1.12$, and at 365 days: $2.14(0-7) \pm 2.37$. The mean preoperative ODI was $37 \%(28 \%-40 \%)+3.06$, and at 365 days $9.52 \%(0 \%-40 \%)+13.92$. The prognosis (ODI) was good to 79 (71.81\%) patients at 365 days, regular in $26(23.63 \%)$ and poor in $5(4.57 \%)$, corresponding respectively to patients with no, mild, moderate and severe disability. The Macnab criteria showed similar results $(p=0.00,95 \%$ $\mathrm{Cl} 0.00$ to 0.13 - Student's t). Conclusions: The results were good at one-year follow-up $(p=0.00)$, demonstrating that the MPN is still a good option for lumbosciatic pain relief.
\end{abstract}

Keywords: Diskectomy, Percutaneous; Intervertebral disc; Hernia; Low back pain.

\section{RESUMO}

Objetivos: Descrever os resultados funcionais dos pacientes com hérnia de disco lombar contida (L4-L5, L5-S1) tratada com nucleotomia percutânea manual (NPM) e demonstrar que continua sendo uma técnica com bons resultados. Métodos: Estudo prospectivo, longitudinal com 110 pacientes com hérnia de disco lombar (HDL) contida tratados com NPM. A avaliação foi pré-cirúrgica e 4, 30, 180 e 365 dias depois da operação; utilizamos Escala Numérica de Dor (END), Índice de Incapacidade Funcional de Oswestry (ODI) e critérios de Macnab. Estatística descritiva e inferencial para diferenças. Resultados: $N=110: 58$ (52,72\%) homens, 52 (47,27\%) mulheres; média de idade 37,95 anos (14-56) \pm 10,60; nível mais afetado: L4-L5 em 63 (57,14\%) pacientes. END pré-operatório média: 7,75 (5-9) \pm 1,12; aos 365 dias: 2,14 (0-7) 2,37. O ODI pré-operatório médio foi 37\% (28\%-40\%) $\pm 3,06$, e aos 365 dias $9,52 \%(0 \%-40 \%) \pm 13,92$. O prognóstico (ODI) foi bom em 79 (71,81\%) pacientes aos 365 dias, regular em 26 (23,63\%) e ruim em 5 (4,57\%), correspondendo, respectivamente, a pacientes sem incapacidade ou leve, moderada e severa. Os critérios de Macnab mostraram resultados similares ( $p=0,00, I C$ 95\% 0,00-0,13 - $t$ de Student). Conclusões: Os resultados foram bons em um ano de acompanhamento $(p=0,00)$, demonstrando que a NPM continua sendo uma boa opção para o alívio da dor lombociática por HDL.

Descritores: Discotomia percutânea; Disco intervertebral; Hérnia; Dor lombar.

\section{RESUMEN}

Objetivos: Describir los resultados funcionales de los pacientes con hernia discal lumbar contenida (L4-L5, L5-S1) tratada con nucleotomía percutánea manual (NPM) y demostrar que continua siendo una técnica con buenos resultados. Métodos: Estudio prospectivo, longitudinal, con 110 pacientes con hernia discal lumbar (HDL) contenida tratados con NPM. La evaluación fue preoperatoria y a los 4, 30, 180 y 365 días después de operados; utilizamos la Escala Numérica del Dolor (END), Índice de Discapacidad Funcional de Oswestry (IDO) y criterios de Macnab. Estadística descriptiva e inferencial para diferencias. Resultados: $N=110: 58$ (52,72\%) hombres, 52 (47,27\%) mujeres; edad promedio 37,95 años (14-56) + 10,60; nivel más afectado: L4-L5 en 63 (57,14\%) pacientes. END preoperatorio promedio: $7,75(5-9) \pm 1,12$; a los 365 días: 2,14 (0-7) $\pm 2,37$. El IDO preoperatorio promedio fue $37 \%$ (28\%-40\%) $\pm 3,06$, y a los 365 días 9,52\% (0\%-40\%) \pm 13,92. El pronóstico (IDO) fue bueno en 79 (71,81\%) pacientes a los 365 días, regular en 26 (23,63\%) y malo en 5 (4,57\%), correspondientes a pacientes sin incapacidad o leve, moderada y severa respectivamente. Los criterios de Macnab mostraron resultados similares, ( $p=0,00$, IC 95\% 0,00-0,13- $t$ de Student). Conclusiones: Los resultados fueron buenos al año de seguimiento $(p=0,00)$, demostrando que la NPM continua siendo una buena opción para el alivio del dolor lumbociático por HDL.

Descriptores: Discectomía percutánea; Disco intervertebral; Hernia; Dolor de la región lumba 


\section{INTRODUCTION}

Low back pain has been identified as the main cause of disability in patients younger than 45 years of age and as the second greatest cause of lost days of work in the United States, ${ }^{1,2}$ affecting almost 10 million people at an estimated cost of more than 20 billion dollars. ${ }^{3-6}$ In Mexico, this disease and its treatment also causes an increase in the workload and consumption of resources. ${ }^{7-9}$ The epidemiology of low back pain is directly related to degenerative disorders of the intervertebral discs, among them herniated discs. ${ }^{10}$ The classical symptoms of a herniated lumbar disc can start with low back pain (lumbalgia) and evolve into radicular pain that we confirm clinically using the Lasègue sign $^{11}$ (sensitivity of $91 \%$, specificity of $\left.26 \%\right)^{9}$ Treatment of this disease can be conservative (changes to daily activities, exercise, analgesics, physiatry, and rehabilitation) or surgical. Percutaneous nucleotomy is a minimally invasive disc decompression technique approved by the Food and Drug Administration (FDA) in the year 2000, ${ }^{12}$ defining it as any discectomy procedure not requiring open dissection of the thoracolumbar fascia. ${ }^{13}$

The technique was first developed by Hijikata, ${ }^{14,15}$ who performed percutaneous decompression and resection of the nucleus pulposus of the intervertebral disc following discography, reporting $60 \%$ to $65 \%$ satisfactory results in his case series. (Figures 1 and 2) The percutaneous nucleotomy, as a minimally
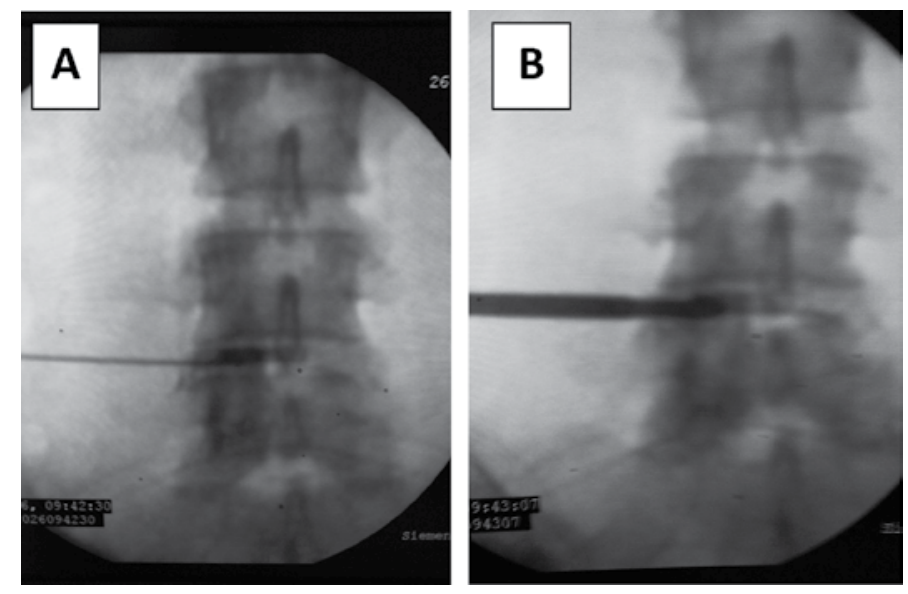

Figure 1. AP fluoroscopic view: A) Discography with guided needle, B) Introduction of the nucleotomy tweezers and extraction of the disc.

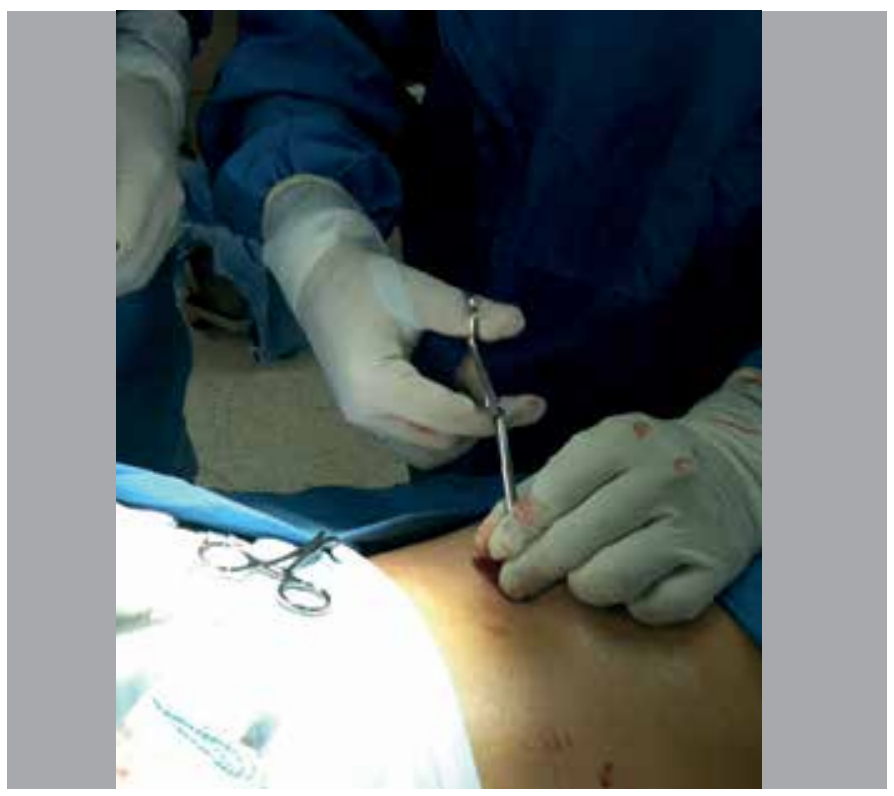

Figure 2. Percutaneous Manual Nucleotomy. invasive decompression technique, enables a reduction of pain and of the complications associated with open intervention (standard discectomy) and an earlier return to daily activities, in addition to reducing the total cost of medical treatment. ${ }^{11}$

However, today it is not widely practiced and whether or not there is clear evidence presented about the superiority of this minimally invasive technique as compared to others is still being debated. There is a lack of high-quality studies to support it or the new techniques being devveloped..$^{13}$

The objective of our study is to describe the functional outcomes of patients with contained lumbar disc hernia (L4-L5, L5-S1) treated with percutaneous manual nucleotomy (PMN) after one year of evolution and to demonstrate that it continues to be a viable technique with good results.

\section{MATERIAL AND METHODS}

Descriptive, longitudinal, prospective, cohort study including patients selected from the outpatient service with low back pain secondary to lumbar disc hernia of L4-L5 and L5-S1. We included those with only one level affected, with chronic lumbosciatic pain previously treated with medications and rehabilitation for more than six months without good response, and who underwent percutaneous manual nucleotomy under fluoroscopy. We excluded those patients with changes in behavior, calcified or non-contained hernias, narrow lumbar canal, spondylolisthesis, congenital deformities, and instability. Patients who wished to leave the study, who did not attend follow-up, or who underwent surgical reintervention were eliminated. All the patients were diagnosed clinically and corroborated by plain radiographs and lumbar magnetic resonance without contrast.

We used a Numeric Pain Scale (NPS) to evaluate pain, the Oswestry Index (ODI) to evaluate functional disability, and the Macnab criteria for the therapeutic evaluation of the clinical results.

The variables used were age, sex, symptom evolution time, complications, NPS, the Oswestry Scale, and the Macnab Criteria. In the numeric pain scale we considered zero to be without pain, 1 to 4 points as mild pain, 5 and 6 points as moderate pain, and 7 to 10 points as severe pain. For the Oswestry Disability Index, the percentage of disability was considered to be minimal from 0 to 20 points, moderate from 21 to 40 points, severe from 41 to 60 points, disability from 61 to 80 points, and exaggerated for 81 points and above. For the Macnab Criteria, results were considered to be excellent when the patient presented no pain or restriction of activity, good when there was occasional pain in the lower back or legs sufficient enough to interfere with the patient's daily life activities or their ability to enjoy leisure time, normal with improved functional capacity but with intermittent pain severe enough to limit or modify work or leisure activities, and poor when there was no improvement or the improvement was not enough to permit increased activity and a new surgical intervention may be necessary. ${ }^{16}$

The NPS and Oswestry scales were applied preoperatively to the patients who met the inclusion criteria, and then at 4, 30, 180, and 365 days following surgery and the results were noted on a data collection sheet. We used the SPSS $\vee 22$ program from IBM.

For the purpose of this study, we considered the results to be good when there was a reduction of 4 points compared to the initial score, when a return to normal activities was possible, and when there were no signs of radicular compression or functional limitation (NPS of 0 to 4 and Oswestry of 0 to 20).

The project was submitted to and approved by the Institutional Review Board of the Hospital Germán Díaz Lombardo (HGDL-NP001), and complies with the ethical and design aspects according to the items registered in the following: Regulations of the General Health Law. According to the regulations of the General Health Law for Research Material, for health, Titles from the first to the sixth and ninth 1987. Technical Norm no. 313 for the submission of research projects and technical reports in health care institutions. Federal regulation: title 45, section 46 and what is consistent with good clinical practices. 
Declaration of Helsinki: ethical principles in medical research on human beings, with the latest revision in Scotland, October 2000. Ethical principles originating in the World Medical Association's Declaration of Helsinki, titled, "All the subjects being studied will sign the informed consent regarding the scope of the study and the authorization for use of the data obtained in scientific presentations and publications, maintaining the anonymity of the participants". The letter of informed consent was accepted.

\section{RESULTS}

There were a total of 100 patients, 58 of whom (52.73\%) were men and 52 of whom (47.27\%) were women, with an average of 37.95 years of age (minimum 14 - maximum $56, \mathrm{SD}=10.60$ years), all operated at one level. The average results of the NPS were 7.75 (minimum 5 - maximum 9), SD 1.12 prior to surgery, 2.43 (minimum 0 - maximum 7) SD 1.88 at 4 days, 2.05 (minimum 0 - maximum 7) SD 2.24 at 30 days, 2.10 (minimum 0 - maximum 7) SD at 180 days, and 2.14 (minimum 0 - maximum 7) SD 2.37 at 365 days. The differences between the NPS values measured prior to surgery and at 365 days are shown in Table 1.

The average Oswestry Disability Index (ODI) was 37 (minimum 28 maximum 40) SD 3.06 prior to surgery, 8.48 (minimum 0 - maximum 34) SD 11.72 at 30 days, 9.33 (minimum 0 - maximum 40) SD 13.84 at 180 days, and 9.52 (minimum 0 - maximum 40) SD 13.92 at 365 days. The differences between the ODI measured prior to surgery and at 365 days are shown in Table 2.

Therapeutic effectiveness was established in our series according to the prognosis based on the ODI, which was good in $79(71.81 \%)$ of the patients, normal in 26 (23.63\%), and poor in 5 (4.57\%) of the patients at 365 days following surgery. According to the Macnab criteria, ${ }^{16} 78$ (71.4\%) patients were excellent or good, 21 (19.08\%) were poor, and 11 (9.52\%) patients were bad at 365 days.

Table 1. Differences reported for the NPS

\begin{tabular}{c|c|c|c|c|c|c|c}
\hline $\begin{array}{c}\text { Time period } \\
\text { reported }\end{array}$ & Mean & Deviation & $\begin{array}{c}\text { Mean } \\
\text { standard } \\
\text { error }\end{array}$ & \multicolumn{2}{|c|}{$\begin{array}{c}\text { 95\% Cl } \\
\text { Inferior Superior }\end{array}$} & $\boldsymbol{t}$ & $\mathbf{p}$ \\
\hline $\begin{array}{c}\text { Preoperative } \\
365 \text { days }\end{array}$ & 5.429 & 2.249 & .491 & 4.405 & 6.452 & 11.062 & .000 \\
\hline
\end{tabular}

Abbreviations: NPS=Numeric Pain Scale, Cl=Confidence Interval, $p=$ significance

Table 2. Differences reported for the ODI.

\begin{tabular}{l|c|c|c|c|c|c}
\hline \multicolumn{2}{l|}{ Time period reported } & \multirow{2}{*}{ Mean } & \multicolumn{2}{|c|}{$\begin{array}{r}\text { C5\% for the dif- } \\
\text { ference }\end{array}$} & \multirow{2}{*}{$\boldsymbol{t}$} & \multirow{2}{*}{$\mathbf{p}$} \\
\cline { 3 - 5 } & & Inferior & Superior & & \\
\hline Preoperative & $\begin{array}{c}365 \\
\text { days }\end{array}$ & 5.42 & 4.40 & 6.45 & 11.06 & .000 \\
\hline
\end{tabular}

Abbreviations: $\mathrm{ODI}=\mathrm{Osw}$ estry Disability Index, $\mathrm{Cl}=$ Confidence Interval, $\mathrm{p}=$ significance

\section{DISCUSSION}

In Mexico, intervertebral disc disease is a highly prevalent socio-economic problem. ${ }^{7}$ Percutaneous manual nucleotomy has been shown to be useful as a disc decompression technique to treat pain in patients with lumbar disc hernia, however, its use continues to be controversial ${ }^{13,17}$ although good results in more than $70 \%$ of the cases are reported in the literature. $4,6,14,15,18,19$ In our study, the average age of the patients was 37.95 years, which agrees with that reported by Hijikata ${ }^{14,15}$ and Stern ${ }^{20}$ while in other studies by Amoretti et al. ${ }^{6}$ and Kallas et al. ${ }^{17}$ the average ages reported were 52 and 46 years, respectively. Another Mexican series $^{3}$ reported an average age of 59.57 years. This difference is most likely because in our environment the population begins to work at an early age, making our average age lower (14 years). In terms of the sex of the patients who underwent intervention, $52.73 \%$ were men and $47.27 \%$ were women, as different from the
Mexican series in which $71.42 \%$ were women. ${ }^{3}$ However similar prospective studies, such as that of Amoretti et al., ${ }^{6}$ note a similar distribution between the sexes (50\% men, 50\% women). On the contrary, Hijikata ${ }^{14,15}$ reports a predominance of males of $60.20 \%$ in his series, which agrees with that reported in our series. Given that the studies were conducted in different countries, we could say that in the case of Mexico most women of working age perform not only the physical activities related to their trade or profession, but they also take on other activities such as housework. However, no correlation with sex has been established. In terms of the level operated, $57.14 \%$ corresponded to level L4-L5 and the remaining percentage to L5-S1 (42.86\%), which is in line with the world literature that mentions that the most frequent presentation of lumbar disc hernia is in the L4-L5 and L5-S1 segments because they are the segments that are respectively the most mobile and the closest to the lumbosacral junction, the area where the greatest support of the spine is concentrated. ${ }^{21}$

In terms of the results of the NPS, an average reduction of 5.70 points was obtained at 30 days $(p=0.00)$, of 5.65 points at 180 days $(p=0.00)$, and of 5.61 at 365 days following surgery $(p=0.00)$ compared with the NPS value obtained prior to surgery, showing a significant improvement in pain. It is worth mentioning that despite the fact that the lowest NPS score was recorded at 365 days, the patients had an average increase of one tenth of a point at 30 days and of one half of a point at 180 days as compared to 30 days $(p=0.00)$. Because this increase was very small, it had no repercussions and no clinical outcome in the pain of the patients. This reduction in the NPS score coincides with the study of Aló et al. $^{4,5}$ in which they reported an improvement of $80 \%(p=0.001)$. However, Amoretti et al. ${ }^{6}$ and Delgado et al. ${ }^{3}$ reported an average reduction of 4 and 3.43 points, respectively. The differences in the average preoperative and preoperative NPS scores at 4, 30, 180, and 365 days were similar and statistically significant $(p=0.00)$, as can be observed in Table 1.

With respect to the Oswestry Disability Index, the average reduction in the percentage of disability was significant from the first postoperative evaluation ( 4 days following surgery, $p=0.000$ ) and continued until disability reached a reduction of 26 percentage points $(p=0.00)$ at one year following surgery, as shown in Table 3, reflecting an improvement in disability from this surgical technique in patients with low back disc hernia.

The difference between the preoperative and postoperative $\operatorname{ODI}(4,30,180,365$ days) was similar and statistically significant $(p=0.00)$ as shown in Table 2 .

In our review of the literature, we found no studies that evaluated the Oswestry disability index, the numeric pain scale, or the Macnab criteria in patients who underwent mechanical percutaneous nucleotomy for lumbar disc hernia. However, other authors have used this for this type of patient, but with percutaneous nucleotomy guided by laser under fluoroscopy, endoscopy, or with dehydration of the intervertebral discs using chemical substances, making a comparison of these studies difficult.

The therapeutic effectiveness of the preoperative Macnab criteria results compared to the postoperative results was good $(p=0.00)$. We did not find any studies that included the numeric pain scale, Oswestry functional disability index, or Macnab criteria in a together in the same study in patients with low lumbar hernias treated with this technique. The success of this treatment in our series

Table 3. Oswestry of the patients, $N=110$.

\begin{tabular}{c|c|c|c|c}
\hline Time of evaluation & Average & Miminum & Maximum & SD \\
\hline Preoperative & 36.8 & 28 & 40 & 4.02 \\
\hline 30 days & 8.80 & 0 & 34 & 12.08 \\
\hline 180 days & 10.40 & 0 & 40 & 16.02 \\
\hline 365 days & 10.6 & 0 & 40 & 15.89 \\
\hline
\end{tabular}

Abbreviations: $\mathrm{N}=$ sample, $\mathrm{SD}=$ standard deviation, \%= Percentage. 
probably depends on proper selection and agrees with Aló et al., 4,5 Amoretti et al., ${ }^{6}$ and Hijikata. ${ }^{14,15}$ Even though this procedure can have complications like discitis, neurological lesions, and vascular lesions, in this study there were no complications. In order to arrive at a complete, integrated evaluation of these patients, we took on the task of using the 3 evaluation scales, something that no study published in the literature has yet undertaken.

\section{CONCLUSION}

The clinical evolution of patients treated with percutaneous manual nucleotomy was good, yielding the therapeutic benefits reported in the literature. It is a minimally invasive surgical technique that should not fall into disuse given that it only requires the percutaneous nucleotomy tool and a fluoroscope to locate the anatomical landmarks. The proper selection of the patient will no doubt allow the maximum benefit to be obtained from the technique and for this reason we conclude that it continues to be a viable technique.

All authors declare that there are no potential conflicts of interest regarding this article.

AUTHORS' CONTRIBUTION: Each author made significant individual contributions to the preparation of this manuscript. PGLR developed the concept and the study design. DBR and BHC performed the critical review and editing. JYVO reviewed the literature and collected the data. JARG and ICV collected the data. DFLL analyzed and interpreted the data.

\section{REFERENCES}

1. Chen $Y$, Derby R, Lee SH. Percutaneous disc decompression in the management of chronic low back pain. Orthop Clin North Am. 2004;35(1):17-23.

2. Nachemson AL. The lumbar spine: an orthopedic challenge. Spine. 1976;1:59-71.

3. Delgado-Álvarez JC, Tamayo-Valenzuela AC, Pérez-Carranco ML, de Jesús Salvador Villafaña-Tello $\mathrm{J}$. The effectiveness of the percutaneous discectomy in the treatment of pain secondary to disc herniation. Rev Med Inst Mex Seguro Soc. 2011;49(2):147-52.

4. Alò KM, Wright RE, Sutcliffe J, Brandt SA. Percutaneous lumbar discectomy: clinical response in an initial cohort of fifty consecutive patients with chronic radicular pain. Pain Pract. 2004;4(1):19-29.

5. Alò KM, Wright RE, Sutcliffe J, Brandt SA. Percutaneous lumbar discectomy: one-year follow-up in an initial cohort of fifty consecutive patients with chronic radicular pain Pain Pract. 2005:5(2):116-24.

6. Amoretti N, David P, Grimaud A, Flory P, Hovorka I, Roux C, et al. Clinical follow-up of 50 patients treated by percutaneous lumbar discectomy. Clin Imaging. 2006;30(4):242-4.

7. Saldívar-González AH, Cruz-Torres DL, Serviere-Zaragoza L, Vázquez-Nava F Joffre-Velázquez VM. Lumbalgia en trabajadores. Epidemiologia. Rev Med IMSS. 2003;41(3):203-9.

8. Guevara-López U, Covarrubias-Gómez A, Elías-Dib J, Reyes-Sánchez A, Rodríguez-ReynaTS. Parámetros de práctica para el manejo del dolor de espalda baja. Cir Cir 2011;79:286-302.

9. Secretaría de Salud. Guía de práctica clínica: diagnóstico, tratamiento y prevención de la lumbalgia aguda y crónica en el primer nivel de atención. México: Secretaría de Salud; 2009.

10. Manchikanti L, Singh V, Falco FJ, Calodney AK, Onyewu O, Helm S 2nd et al. An updated review of automated percutaneous mechanical lum bar discectomy for the contained herniated lumbar disc. Pain Physician. 2013;16(Suppl 2):SE151-84.
11. Matta-Ibarra J, Arrieta-María V, Villarraga-Villabona CM, Rozo-Franco M. Discoidectomía lumbar por incisión mínima. Experiencia Multicéntrica. Rev Col Ortop Traumatol. 2005;2(6):32-8

12. Adam D, Pevzner E, Gepstein R. Comparison of percutaneous nucleoplasty and open discectomy in patients with lumbar disc protrusions. Chirurgia (Bucur). 2013:108(1):94-8.

13. North American Spine Society. Clinical guidelines for diagnosis and treatment of lumbar disc herniation with radiculopathy. USA: North American Spine Society; 2012.

14. HijiKata SA. Percutaneus nucleotomy, for low back pain. In: Sicot XIV Word Congress, Kioto (Japón); 1978. p. 15-20

15. Hijikata S. Percutaneous nucleotomy. A new concept technique and 12 years' experience. Clin Orthop Relat Res. 1989:(238):9-23.

16. Macnab I. Negative disc exploration. An analysis of the causes of nerve-root involvement in sixty-eight patients. J Bone Joint Surg Am. 1971;53(5):891-903.

17. Kallás JL, Godoy BL, Andraus CF, Carvalho FG, Andraus ME. Nucleoplasty as a therapeutic option for lumbar disc degeneration related pain: a retrospective study of 396 cases. Arq Neuropsiquiatr. 2013;71(1):46-50.

18. Saenz-López de Rueda F, Luna-Sánchez C. Nucleotomía percutánea automatizada. Nuestra experiencia. Rev Esp Cir Ost. 1991;26(153):167-71.

19. Kambin P, Geilman H. Percutaneous lateral discectomy of the lumbar spine. Clin Orthop Relat Res 1983;(175):127-32.

20. Stern MB. Early experience with percutaneous lateral discectomy. Clin Orthop Relat Res. 1989:(238):50-5.

21. White AAl, Panjabi MM. Clinical biomechanics of the spine. 2nd ed. Philadelphia: Lippincott; 1990. 